\title{
Effect of Micro-grants on Poverty Alleviation of Palestinian Families (Gaza Strip-Palestinian territories)
}

\author{
Khalil A. El-Namrouty ${ }^{1}$, Wassem Alhabil ${ }^{2}$, Doaa A. Al-thalathini ${ }^{1}$ \\ ${ }^{1}$ Dep't of Economics and Political Science, Islamic University-Gaza, Palestinian territories \\ ${ }^{2}$ Dept of Business Administration, Faculty of Commerce, Islamic University of Gaza, Palestinian Territories
}

\section{Email address:}

knamroty@iugaza.edu.ps (K. A. El-Namrouty),walhabil@iugaza.edu.ps (W. Alhabil), thalathini.doaa@gmail.com (D. A. Al-thalathini)

\section{To cite this article:}

Khalil A. El-Namrouty, Wassem Alhabil, Doaa A. Al-thalathini. Effect of Micro-Grants on Poverty Alleviation of Palestinian Families (Gaza Strip- Palestinian Territories). Journal of World Economic Research. Vol. 2, No. 5, 2013, pp. 82-88.

doi: $10.11648 /$ j.jwer.20130205.11

\begin{abstract}
The research paper aimed to identify the impact of micro-grants in the poverty alleviation of Palestinian families in Gaza Strip who suffer from extreme poverty through the transfer of assets to start economic activities to improve their livelihood strategies and provide them with skills and experience to contact Microfinance Institutions taking Deprived Families Economic Empowerment Program (DEEP) as a case study. Results showed positive impact of the program in reducing poverty and unemployment rate, projects are the main source of income for many benefited families, they achieved a rise in their income after getting the grant and improved their expenditure on basic necessities. Poor families also feel that they are more independent after the project, and they can support themselves from their current income. Although these projects have not yet sufficiently developed to be able to dispense relief aid, the political and economic circumstances of the Gaza Strip had a negative effect on the performance of the projects.
\end{abstract}

Keywords: Palestinian Families, Gaza Strip, Extreme Poverty, Economic Sustainability, Micro-Grants, DEEP

\section{Introduction}

Palestinians through the past decades faced many crises and wars that led to the high rate of poverty and unemployment among local citizens, which necessitated the provision of social protection programs represented in the role played by the formal and informal institutions to provide financial and in-kind assistance for poor families. But this aid does not alleviate poverty and unemployment, so it has been necessary to set strategic plans to alleviate the poverty intensity to pave the way for poor families to find jobs and change their families' livelihood status from relief assistance to self-sufficiency families for its members (Qasem, 2007).

Many poor Palestinian families have resorted to create economic projects for life insurance through borrowing from Microfinance Fund Institution. Despite the importance of microfinance to struggle against poverty, it is noticed that a large number of poor people, especially the very poor, reject dealing with such loans as it is presently granted because they require paying regularly. Since the primary cause of poverty is the lack of a steady income, thus affects on fulfilling its commitment to financial and non-interest of these families to take advantage from the available loans or due to the rejection of the institutions to their applications because of their inability to meet the necessary

Hashemi and Montesquiou (2011), Widjaja (2009), and Davis (2005) consider that Microfinance Fund Institution play an important role in helping poor families to get financial funding required to create or develop their small projects, but the funding programs become improper for all these families especially who struggle daily for survival and have inner fear and lack of self-confidence in the belief of not being able to repay which lead them to become debtors, in addition to the non-arrival of institutions for this marginalized group of people. Microfinance, in general, becomes proper at the existence of the economic activities and the sufficiency of cash flow for the family; in other cases it may create an additional burden. So these researchers recommended the need to build the abilities of these poor people, and encourage them to save, and let assets be transferred to help them in the start of sustainable economic activities, and therefore they get a sufficient 
confidence for microfinance services.

Therefore there is a need for the existence of complementary strategies to reduce poverty, where grants can represent small first step in the integrated programs aimed at the rehabilitation of the poor to rely on themselves. As a recompense to the microloans, the grants can be benefited in a better way to participate in economic activities and learn saving as a beginning to rehabilitate them to take advantage from the microloans. Therefore, the study aims to clarify the impact of micro-grants to help poor families in poverty alleviation and economic selfdependence and self-sustainability instead of relying on humanitarian aids through the development of human capital and its integration into the labor market through rehabilitation, training and the provision of grants.

\section{Poverty in the Palestinian Territories}

Palestinian Central Bureau of Statistics (2012) state that a quarter of the Palestinian population suffered from poverty in 2011, where the percentage of poverty among Palestinian individuals during the year 2011 according to the monthly consumption patterns reached $25.8 \%(17.8 \%$ in West Bank and 38.8\% in Gaza Strip). Also, it was found that a rate of $12.9 \%$ of the individuals suffered from extreme poverty according to the monthly consumption patterns (7.8\% in West Bank and 21.1\% in Gaza Strip). On the other hand, the poverty percentage increased according to the monthly consumption patterns in by $0.39 \%$ in 2011 compared with 2010 .

Number of poor families in the Palestinian territories increased between 1998 to 2011 by $27.1 \%$, and the percentage of families that suffered from extreme poverty increased in a rate of $3.2 \%$ during the same period. This remarkable increase resulted from the existence of the Israeli occupation which controls the social and economic development of the Palestinian people, and the continuance of the policy of non-stop closure to West Bank and Gaza Strip resulting policies, procedures and practices led to deforming the Palestinian economy, looting its natural resources, and deepening dependence on the Israeli economy, and reducing the chances of progressing the field of economic development (National Coalition Antipoverty, 2007).

\section{Antipoverty Programs in the Palestinian Territories}

The trend of the Palestinian National Authority to struggle against poverty can be monitored through two approaches: the first one aims to reduce poverty and provide social assistance to poor families through the social protection program and the protection of the poorest in which the Ministry of Social Affairs, which is considered the main resource to the social assistance throughout the country, providing cash assistance for poor families depending on their size and expenditures ranging from $\$ 70$ to $\$ 200$ every three months funded by the European Union, the World Bank, and the Palestinian National Authority for about 93,947 families in which 45,923 families live in Gaza Strip, and 48,024 families live in the West Bank, most of them are extremely poor families. As food aid is offered in partnership with the World Food Program, and about 45,000 families in the Gaza Strip and West Bank presently benefit from this aid. The ministry in cooperation with the Palestinian Ministry of Health also provides health insurance services for about 75,000 poor rural families in which 48, 262 families live in West Bank and 26,738 families live in Gaza Strip ${ }^{1}$.

The second approach towards the development of preventive programs and development aimed at supporting families that can overcome poverty through the development of mechanisms and programs that develop the size of the poor families and the marginalized groups and promote the self-reliance through the provision of grants and loans to establish economic and income-earning projects, vocational training program, urgent operation and operation fund concentrating on the disadvantaged group of people to access to the labor market such as graduates and women. Despite the importance of programs to create jobs, it remains as relief programs, and does not solve the problem of unemployment in the medium or long term, and therefore cannot be considered a development strategy to confront the problem of poverty. The period of operation which is limited to 3 months does not contribute to solve the problem of poverty or unemployment, and does not include the development of beneficiaries skills or helping them to get a real job later; this requires reconsideration of how to develop these programs and convert them to real job opportunities by relating it with vocational training programs (UNDP, 2008).

As the Palestinian Non-Governmental Institutions provide financial and in-kind assistance, vocational rehabilitation, medical, training, and microloans programs for the poor families and the marginalized groups such as Zakat (Charity) Committees, Al-Salah Charities, charitable associations, and other (www.mosa.pna.ps-on 16/08 / 2012). However, these institutions rely heavily on the external financing; its programs are usually related to specific occasions or seasons, and lack the sustainability or to a regular schedule; therefore, the institutions do not require to institutionalize their assistance or develop objective criteria for identifying beneficiaries affecting on the efficiency and sustainability of such programs.

The international institutions (UNRWA), which is one of the most important international institutions that provide social assistance to poor families in the Palestinian territories, occupied the second in terms of providing the service after the Ministry of Social Affairs. UNRWA

\footnotetext{
${ }^{1}$ Phone interview with the Deputy General Manager of the General Management for Antipoverty in the Ministry of Social Affairs in Ramallah, September 2012.
} 
through the social safety net provides food aid and cash on a regular basis, and health and education services for Palestinian refugees. In addition, it provides emergency assistance program which aims to provide emergency assistance to Palestinian refugees during crises caused by war, conflict or natural disasters. UNRWA has also established special programs of microfinance in 1991 which has provided income-earning opportunities for Palestinian refugees and other groups of poor or marginalized, but it does not take into account the criteria of poverty. (Parvathaneni, 2004).

A report was published by UNRWA in 2009 explained that its assistance even though it had an obvious effect in reducing the severity of poverty, is the not a major factor in reducing poverty rates and numbers of poor refugees due to the continuing deterioration is the economic and social conditions that made such assistance is not sufficient to stop the rampant poverty among Palestinian refugees. The report stated that the solution to the problem of poverty through access to all Palestinian territories, breaking the siege on Gaza Strip and ending the isolation between West Bank and Gaza Strip and then the outside world where it will be so encouraging for the local and international markets and creating an enough employment opportunities to employ the Palestinian youth and laborers which lost its work within the Israeli market in the past (UNRWA, 2009).

Ministry of Social Affairs is aspiring to put the leading plan to develop a mechanism identifying the poor, and then determining the quality and quantity of their requirements, and after that converting the families which have the ability to manage projects into granting and lending programs which qualify them to rely on themselves in the income. The trend of mid-range Strategic Plan 2010-2015 for UNRWA to modernize the system of assistance to the poor so as to achieve higher efficiency in targeting, and stabilize the integration between the relief and development dimension in their programs through the provision of health and education services, increasing the lending services and saving opportunities for the marginalized and the poor, and improving the opportunities of getting a job (Palestine Economic Policy Research Institute, 2012).

\section{Economic Empowerment Program for Disadvantaged Palestinian Families}

In mid of 2007, the United Nations Development Program UNDP implemented a trial program for families that suffer from poor chronic in the occupied Palestinian territories; it is the economic empowerment program for disadvantaged families - Deep (Deprived Families Economic Empowerment Program) during 30 months and its budget reached to 30 million U.S. dollars. The program is funded by the Islamic Development Bank and some other Arab funds and in partnership with the Palestinian National
Authority (Ministry of Social Affairs, Ministry of Planning, and Ministry of Labor). The program is primarily aimed to enable the Palestinian families who suffer from poverty and extreme poverty and help them to be transferred from recipients of humanitarian assistance into economic selfsustainability through the development of human capital and its integration into the labor market through rehabilitation, training, providing grants and soft loans, encouraging the small enterprises. The program also aims to develop the abilities of institutions working in this field, so as to achieve its goals more efficiently and effectively, and support the poor in a better way to contribute to reducing the poverty at the national level (Birzeit University, 2008).

Deep program consists of two main components of services targeted to the poor directly; first, includes a range of financial services activities (Islamic Microfinance), and the second component includes a range of non-financial services activities (Economic Empowerment Grants). The aim of the integration of the two services is to help disadvantaged families to use the component grants to build the necessary economic infrastructure, and then seek to achieve sustainability and economic independence through microfinance (El-Madhoun et al., 2009).

Until the end of the year 2011, the program had targeted about 6,600 poor Palestinian families including nearly 36 million U.S. dollars in which about 4,400 families benefited from the granting of economic empowerment. The average value of the grant provided about 5,530 U.S. dollars for each family. Also, about 1,841 families benefited from the Islamic microfinance with total value of 6,35 million U.S. dollars (UNDP, 2011). DEEP beneficiaries funded by Japan Fund received 12-day training ${ }^{2}$.

\section{Literature Review}

Sseveral previous studies discussed the role of microenterprises and grants in reducing poverty. Sample study (2011) called for a campaign period of ten years to take out a hundred million families out of extreme poverty in a sustainable manner through creating programs to identify and help the poorest beneficiaries to make them more willing to microfinance programs, and to provide additional services besides funding such as health care, grants and training which contribute to the continuity of the family's success in overcoming poverty.

The studies of Ghalib (2010), Shayeb (2010), Salman (2009), Al-Ameen (2009), Samir and Mehdi (2005), and Al-Naqa (2004) talked about the role of small projects in reducing poverty and unemployment since it exerts hard efforts to improve the economic and social situation for the family as a result of increased income, savings, and give them ability to cope with any crisis of their lives. It also helps them to develop their management skills, and

\footnotetext{
${ }^{2}$ Phone interview with the training program coordinator in the Small Enterprises in Gaza Strip, August 2012.
} 
increase the level of confidence and a sense of respect for others. Also, the studies of Al-Zyadat(2008), and Ahmed and Abdul Karim (2007) showed the ability of small projects to create jobs for a large number of the workforce and an income for them and the owners of these projects which contribute to raising the standard of livelihood for many groups of the community.

The study of Hashemi \& Montesquiou (2011) and study of Hashemi \& Rosenberg (2006) focused on the safety net programs to help a large number of families in Bangladesh to overcome extreme poverty. The program is based on five stages: the right selection of poor families, providing food safety, encouraging saving, transferring of assets to the participants to help start sustainable economic activities, and participants training on the managerial skills which enable them finally to access to microfinance services. The study of Krysher \& Kock (2010) aimed to evaluate the micro- grants program which targeted Afghans, particularly women. The study showed that micro-grants results in increasing assets and income of the beneficiaries, and improving their livelihood conditions and their ability to provide the basic needs of their families, including education, and increasing the number of employees in projects.

The studies of Widjaja (2009), Davis (2005), and Swope (2005) showed that the microfinance programs are not suitable for all poor families which have inner fear and lack of self-confidence since they have the belief of not being able to pay or access microfinance institutions for these marginalized people. And that microfinance programs is not always the adequate solution to the problems related to poverty especially for those people who are struggling every day to survive, it has to be beside a range of other social programs which are flexible to meet the diverse needs of poor families.

The study and Peace Parker (2002) pointed out that the microfinance is one of several interventions that should be used to alleviate poverty. And to benefit from microfinance programs, it should first have managerial skills and high confidence and a sound financial basis for the beneficiaries of these programs. The micro- grants are considered as the starting point for the poor to empower them and invest time and resources to learn skills and build assets and develop plans and thinking in investment activities. The study of Abu Bakr (2001) recommended providing poor people who are unable to work with productive tools or help them build productive small projects in order not to rely on relief aid.

As mentioned above the importance of the study emerges as it sheds light on the role played by micro-grants to start micro-enterprises in the Palestinian environment to help the families that suffer from extreme poverty to overcome this situation and access to microfinance programs without being rejected or not being able to repay through the establishment of proper economic infrastructure and the presence of an existing and income-earning project can develop it, and thereby achieve the economic independence through a case study of the program "DEEP".

\section{Methodology}

Based on the nature and study goals, a descriptive analytical method has been used, Secondary sources, consists of Arab and foreign relevant books and references, journals, articles, reports, research, previous studies and Internet web sites. Researchers collected primary data through a questionnaire, which is the key means of the study. The questionnaire was designed and distributed to the beneficiaries of economic empowerment program (Deep), and then discharged and analyzed by using the SPSS program in order to calculate ratios and the use of statistical tests.

The questionnaire designed to test the effects of microgrants on household performance, such as the, effects on income generation, life style, accommodation, business expansion etc.. It is consisted of 18 items and quintet Richter scale has been relied onto measure the responses to the items of the questionnaire, and the answers to each item consist of 5 choices in which class "1" means agree to a low extent and class " 5 " means agree to a great extent.

Table No. (1): Quintet Richter scale

\begin{tabular}{llllll}
\hline Weight & 1 & 2 & 3 & 4 & 5 \\
$\begin{array}{l}\text { Descriptive } \\
\text { interpretations }\end{array}$ & $\begin{array}{l}\text { Strongly } \\
\text { disagree }\end{array}$ & Disagree & Neutral & Agree & $\begin{array}{l}\text { Strongly } \\
\text { agree }\end{array}$ \\
\hline
\end{tabular}

The targeted community consisted of Palestinian families who suffer extreme poverty and whose names are registered in the Ministry of Social Affairs in Gaza Strip which has benefited from the economic empowerment program (DEEP), they are about (482) beneficiaries. The community of study has chosen a random sample, and a number of 170 questionnaires were distributed proportionately to the geographical distribution of projects implemented as shown in Table No. (2).

Table No. (2): Distribution of Sample on Provinces

\begin{tabular}{lllll}
\hline No. & Province & $\begin{array}{l}\text { No. of Projects } \\
\text { implemented }\end{array}$ & $\begin{array}{l}\text { Size of } \\
\text { Sample }\end{array}$ & $\begin{array}{l}\text { Rate of } \\
\text { Sample (\%) }\end{array}$ \\
1 & North & 105 & 37 & 21.8 \\
2 & Gaza & 99 & 35 & 20.6 \\
3 & Middle areas & 54 & 19 & 11.2 \\
4 & Khan Younis & 109 & 38 & 22.4 \\
5 & Rafah & 115 & 41 & 24 \\
\multicolumn{2}{l}{ Total } & $\mathbf{4 8 2}$ & $\mathbf{1 7 0}$ & $\mathbf{1 0 0}$ \\
\hline
\end{tabular}

The researchers used a composite of statistical tools to treat the data in this study. They used the following statistical techniques to make the interpretation of the data:

- The mean which is a central tendency measure representing the arithmetic average of a set of observations. The researcher gave values of how much agreement or disagreement with questionnaire items as shown in table (2).

- Kolmogorov-Smirnov Test to test if the data 
gathered follows normal distribution or not.

- $\quad$ Sign test was used to know if the average degree of response had reached a medium degree of approval (neutral), a 3. Results are shown in Table (3).

Table No. (3): Average Arithmetic of micro-grants effect on beneficiaries

\begin{tabular}{|c|c|c|c|c|c|c|}
\hline No. & Item & $\begin{array}{l}\text { Average } \\
\text { Arithmetic }\end{array}$ & $\begin{array}{l}\text { Relative Average } \\
\text { Arithmetic }\end{array}$ & $\begin{array}{l}\text { Value of } \\
\text { Test }\end{array}$ & $\begin{array}{l}\text { Value of } \\
\text { Possibility (Sig.) }\end{array}$ & Rank \\
\hline 1. & $\begin{array}{l}\text { The project is the current main source of } \\
\text { income for family. }\end{array}$ & 4.35 & 87.07 & 9.24 & $* 0.000$ & 1 \\
\hline 2. & $\begin{array}{l}\text { The family feels that its income has } \\
\text { increased after the project. }\end{array}$ & 3.70 & 74.01 & 7.08 & $* 0.000$ & 7 \\
\hline 3. & $\begin{array}{l}\text { The impact of the project is considered } \\
\text { positive to the family. }\end{array}$ & 3.72 & 74.37 & 6.86 & $* 0.000$ & 6 \\
\hline 4. & $\begin{array}{l}\text { The project income leads to improve the } \\
\text { family expenditure on food }\end{array}$ & 4.04 & 80.72 & 9.40 & $* 0.000$ & 3 \\
\hline 5. & $\begin{array}{l}\text { The project income leads to the family } \\
\text { expenditure on clothes. }\end{array}$ & 3.50 & 69.94 & 6.15 & $* 0.000$ & 10 \\
\hline 6. & $\begin{array}{l}\text { The project income leads to improve the } \\
\text { family expenditure on joining the family } \\
\text { members in education. }\end{array}$ & 3.51 & 70.18 & 5.51 & $* 0.000$ & 8 \\
\hline 7. & $\begin{array}{l}\text { The project income leads to improve the } \\
\text { family expenditure on health. }\end{array}$ & 3.03 & 60.60 & 0.17 & 0.431 & 13 \\
\hline 8. & $\begin{array}{l}\text { The project income leads to improve the } \\
\text { family expenditure on housing. }\end{array}$ & 2.54 & 50.90 & -6.96 & $* 0.000$ & 15 \\
\hline 9. & $\begin{array}{l}\text { The project income leads to improve the } \\
\text { family psychological status. }\end{array}$ & 3.99 & 79.76 & 8.26 & $* 0.000$ & 5 \\
\hline 10. & $\begin{array}{l}\text { The number of laborers increased after } \\
\text { the project. }\end{array}$ & 4.11 & 82.28 & 10.99 & $* 0.000$ & 2 \\
\hline 11. & $\begin{array}{l}\text { The family pays the previous financial } \\
\text { commitments such as debts after the } \\
\text { projects. }\end{array}$ & 3.08 & 61.56 & 2.69 & $* 0.004$ & 12 \\
\hline 12. & The family saves after the project. & 1.93 & 38.56 & -8.77 & $* 0.000$ & 17 \\
\hline 13. & $\begin{array}{l}\text { The family can use its savings to } \\
\text { develop its current project. }\end{array}$ & 1.90 & 37.96 & -8.93 & $* 0.000$ & 18 \\
\hline 14. & $\begin{array}{l}\text { The family feels that it has become more } \\
\text { independent after the project. }\end{array}$ & 3.50 & 70.06 & 5.28 & $* 0.000$ & 9 \\
\hline 15. & $\begin{array}{l}\text { The family thinks that they can support } \\
\text { themselves from their current income. }\end{array}$ & 3.39 & 67.78 & 4.29 & $* 0.000$ & 11 \\
\hline 16. & $\begin{array}{l}\text { The family can dispense with the relief } \\
\text { aids after the project. }\end{array}$ & 2.44 & 48.74 & -4.78 & $* 0.000$ & 16 \\
\hline 17. & The family develops the current project. & 2.84 & 56.75 & -2.22 & $* 0.013$ & 14 \\
\hline 18. & $\begin{array}{l}\text { The beneficiary has an intent to develop } \\
\text { the current project in the future. }\end{array}$ & 4.03 & 80.60 & 9.38 & $* 0.000$ & 4 \\
\hline All items & & 3.31 & 66.20 & 4.86 & $* 0.000$ & \\
\hline
\end{tabular}

* Average Arithmetic indicates statistically on the element $\alpha=0.05$

\section{Results}

1. $87.07 \%$ of the study sample believes that Project is the main source of present income, and $74.01 \%$ of achieved a rise in income after obtaining the grant. Also, $74.37 \%$ of the study sample considered that the impact of the project was positive to them, and $61.56 \%$ of the study sample pays their accumulated debts.

2. Families' expenditure goes for basic needs such as, $80.72 \%$ on food and $70.18 \%$ and $69.94 \%$ on education and clothing respectively.

3. With regards to reducing unemployment rates among family members the number of employees in the family has increased after the project at a rate of $82.28 \%$. Furthermore $70.06 \%$ of families feel that they are more independence after project, and $67.78 \%$ of families can support themselves on their current income.

4. $37.96 \%$ of the study sample was able to use their savings to develop their current project, and 3.6\% of the study sample converted to the lending institutions.

5. Although these projects have not yet developed sufficiently so that they can dispense relief aid and that what was said by $48.74 \%$ of the study sample, the field is still open to these projects for the development, and showed a rate of $80.6 \%$ of the study sample that they have the intention to develop the project in the future as income-earning projects need time until you reach a state of economic stability to enable them to strive towards sustainability, as the beneficiary families need frequently to continue to reinvest parts of the income of the project to raise the capital to purchase productive assets or goods to enable them to expand its activities to enable the project to stability, and the poor economic conditions experienced by the sector has had a negative impact on the income of most of these projects. The difficult conditions experienced by the Palestinian society in general 
make relief and humanitarian aid as a livelihood strategy for many years, so it lacks the concept of development and self-reliance to secure a steady income to support themselves. They get familiar with the aids which are considered their right, and perhaps some of the families that benefited consider the grant as a kind of relief aid as well. Therefore, it is necessary to adopt a social and educational policies aiming to create a culture of development among members of the society, especially many families rely on aid for many years as a key strategy in livelihoods. The development of integrated development plans aims to create jobs for the poor, and the participation of the poor themselves in the formulation of these plans and strategies.

\section{References}

[1] Abu Bakr, Ola (2001). Determinants of poverty and its impact on urban development in the province of Naples. Master thesis, Al-Najah National University, Nablus, Palestine.

[2] Ahmed, Dhaief and Abdul Karim, Al-Bashir (2007). Microloans Experience Assessment in Algeria as a Mechanism to Antipoverty. A Study Introduction to the International Symposium on the Experiences of Antipoverty in the Arab and Muslim worlds, Blida, Algeria.

[3] Al-Ameed, Idris (2009). Role of financial institutions in financing small projects in Sudan. Master Thesis, University of Sudan for Science and Technology, Khartoum, Sudan.

[4] Barghouthi, Khaled, Deputy Director General of Public Administration of Antipoverty in the Ministry of Social Affairs, Ramallah, a telephone interview on 05.09.2012.

[5] Birzeit University (2008). The Economic Empowerment of Palestinian Families. Procedural Manual Draft as an Introduction to the United Nations Development Program (UNDP), Continuing Education Center - Birzeit University, Birzeit, Palestine.

[6] Davis, Lea (2005). Does Microfinance Help the Poorest? What Programme Design Features Might Maximise Impact on the Poorest Clients? Master Thesis, RMIT University, Melbourne, Australia.

[7] El-madhoun, R.; Sourani, I.; Farr, V.; Nakhleh, H.; and Darwish, D. (2009). DEEP: a New Approach to Poverty Reduction. In Fenton W., Editor. Humanitarian Exchange, Number 44, Humanitarian Practice Network (HPN), Overseas Development Institute, London.

[8] Ghalib, Nabiylah (2010). The Role of Small Enterprises in Reducing the Problem of Poverty and Unemployment in Yemen: a Field study in the Capital City of Sana'a. Ph.D. Thesis, University of Jordan, Jordan.

[9] Hashemi, Sayed and De Montesquiou, Aude (2011). Reaching the Poorest: Lessons from the Graduation Model. CGAP, Focus Note 69, Washington, D.C.

[10] Hashemi, Sayed and Rosenberg, Richard (2006). Graduation the poorest into Microfinance: Linking Safety Net Programs and Financial Services. CGAP, Focus Note 34, Washington, D.C.
[11] Hassouna, May, Coordinator of the Training Program, the Small Enterprises Center, Gaza, a Telephone Interview on 06/08/2012.

[12] Krysher, Sheyenne and Kock, Timothy (2010). The Use of Micro-grants to Mitigate Gender Inequity in Afghanistan by Empowering Rural Farmers and Agribusiness Entrepreneurs. Journal of International Agricultural and Extension Education, Volume 17, Number 1.

[13] National Coalition of the Universe Call to Antipoverty in Palestine (2007). Millennium Development Goals in Palestine- The Possibilities and Obstacles. Ramallah, Palestine.

[14] Al-Naqa, Khalil (2004). Impact of microcredit programs Case Study lending program of UN Relief and Works Agency for Refugees. Master thesis, Islamic University of Gaza, Palestine.

[15] Parker, Joan and Peace, Doug (2002). Microfinance, Grants, and Non-Financial Responses to Poverty Reduction: Where Does Microcredit Fit?. CGAP, Focus Note 20, Washington, D.C.

[16] Palestinian Central Bureau of Statistics (2012). Standards of Livelihood in the Palestinian Territories: Spending, Consumption, Poverty 2011. Ramallah, Palestine.

[17] Palestine Economic Policy Research Institute -March (2012). Social Security in the Palestinian territories: The Current Situation and the Challenges as an Exploratory Study. Jerusalem, Palestine.

[18] Parvathaneni, Harish (2004). UNRWA's Role in Protecting Palestine Refugees. BADIL Expert Forum, Al-Ahram Centre for Strategic and Political Studies, Working paper no. 9, Cairo, Egypt.

[19] Qasem, Ahmad (2007). Poverty in Palestine: Numbers and Facts. Web Page, dated on February21, 2012.

[20] Salman, Maysa' (2009). The development effect of small projects funded under the development strategy-An Empirical Study on projects funded by the operating and development projects. Master thesis, Arabic Open Academy in Denmark.

[21] Samir, Aiyat and Mahdi, Nasser al (2005). Microloans and its Role for the Antipoverty. Sa'ad Dahlab Blida University and the University Center, Khamis Miliana, Algeria.

[22] Sample, Bob (2011). Moving 100 Million Families Out of Severe Poverty: How Can We Do It?. Paper papered for Global Microcredit Summit, Valladolid, Spain.

[23] Shayeb, Ihab (2010). The Impact of Microfinance on the Livelihood Level of the Target Group. Master Thesis, Ain Shams University, Cairo, Egypt.

[24] Swope, Tessie (2005). Microfinance and Poverty Alleviation. Independent Study on Microfinance.

[25] UNDP (2011). Project Fact Sheets of Deprived Families Economic Empowerment Program- DEEP. AlBeirah, Palestine.

[26] UNDP (2008). Needs Assessment Survey Results for the Potential Beneficiaries of the Deprived Families Economic Empowerment Program "DEEP". Study submitted by AlSahel Company for Institutional Development \& Communication, Jerusalem, Palestine. 
[27] UNRWA (2009). Poverty in the occupied Palestinian Territory (2007). Briefing Paper, Jerusalem, Palestine.
[28] Widjaja, Henky (2009). Microcredit (not) for the Poor - A Misleading Panacea Assumption. 